\title{
Integration of land use and transportation within the CBD of an intermediate city: a case study of Tlokwe local municipality, South Africa
}

\author{
I. M. Schoeman \\ Mathematics and Applied Mathematics, \\ North West University, South Africa
}

\begin{abstract}
The Tlokwe Local Municipality (Potchefstroom) (secondary node) is located on the N12 corridor between Johannesburg as (primary node) through Kimberley (secondary node) to Cape Town (primary). This location reality implies that some $65 \%$ of the inter traffic consists of heavy motor vehicles transporting freight that is passing through the Central Business District (CBD) of Potchefstroom based on origin and destination movement patterns between the high order nodes within the national spatial system. These traffic movement patterns result in traffic congestion that impacts negatively on the intra-traffic flows within the CBD of Potchefstroom and its spatial land use development, consolidation, growth, urban renewal, internal movement patterns and local accessibility.

The research includes a literature overview of land use and transportation integration; study of inter-traffic movement patterns (regional) and traffic volumes for intra-traffic movements in terms of modal split; detailed land use and parking surveys within the study area. Inclusive in the research methodology is a quantitative research approach supported by a qualitative research survey as to identify local experience, patterns and perceptions related to the research problem.

This elementary modeling and simulation output is supported in the demarcation of the CBD boundary based on land use and transportation integration considerations and related tendencies within the study area. The devised elementary technique will be used to project the future land use patterns
\end{abstract}


for development, impact of traffic patterns and development strategies for spatial development within the study area.

Keywords: inter-traffic, intra-traffic, land use, transportation planning, modal integration, land use and transportation modeling.

\section{Introduction}

This paper analyzes existing transport and land-use patterns based on an elementary modelling application from which development strategies can be formulated. The goal will be to encourage less travel, especially by heavy motor vehicles and by private car in the CBD of Tlokwe Local Municipality (TLM).

Numerous approaches have been developed internationally to investigate the complex interaction, integration and interface between transport and land use [1]. The point of departure of the various approaches differ due to local differences, interactions that take place over different time scales, application of factors with different degrees of certainty and its related goals and objectives. The different land-use and transport models are difficult to compare since the models have been developed for different purposes [2].

\section{Research approaches}

\subsection{Quantitative research approach}

The research methodology applied includes the following focuses: literature considerations; research problem, case study, case study results (traffic surveys) and strategy formulation for spatial and transportation development. Due to the format of this paper, the quantitative and qualitative methodologies that follow will be integrated.

\subsection{Qualitative research approach}

\subsubsection{Regional reality of inter-traffic movements}

Figure 1 shows the dominant inter-traffic movements affecting the study area. Due to the fact that the inter-traffic moves through the Central Business District (CBD) of the study area, traffic congestion occurs during both peak and off-peak hours. This is due to the conflict in inter-and intra traffic movement patterns.

\subsubsection{Intra-traffic movements within the study area}

Figure 2 shows the dominant intra-traffic movements within the study area inclusive of the inter-traffic movements through the study area. From an analysis of the traffic data some $87 \%$ of the through traffic flows for freight are attributed to origin and destination outside the study area [3]. This conclusion is supported by an analysis of the 2007 North and South Weight Bridge data on the N12 Route or corridor. The inter-traffic movements and the clashing intra-traffic movements is the main cause of severe traffic congestion that includes all modes of traffic. 


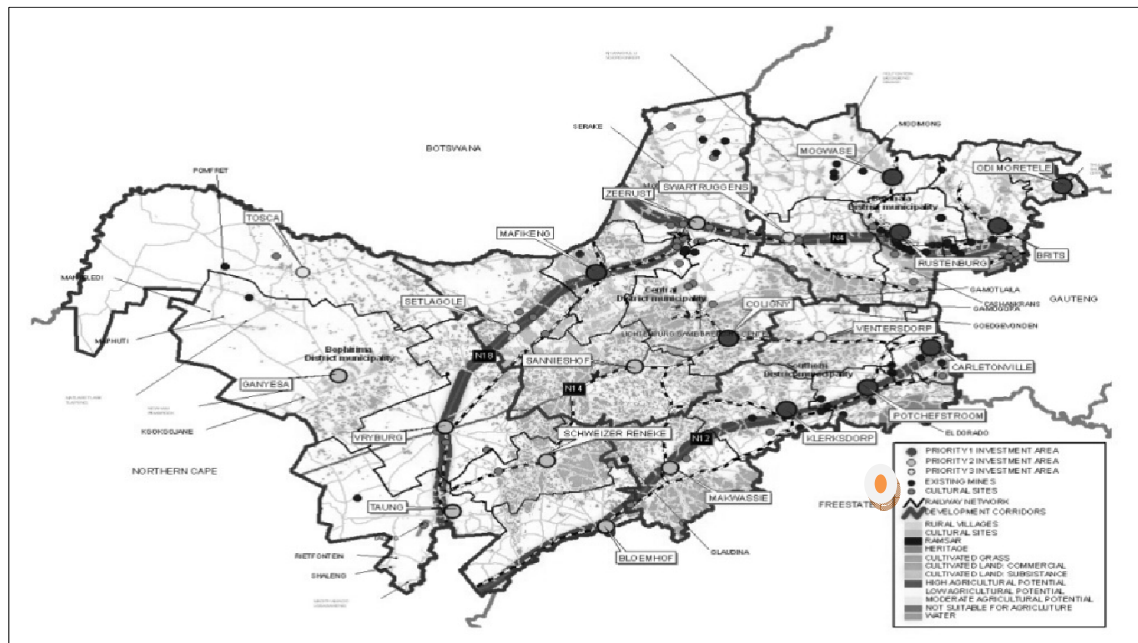

Source: NWPSDF [4].

Figure 1: Regional perspective of inter-traffic movements within the North West Province.

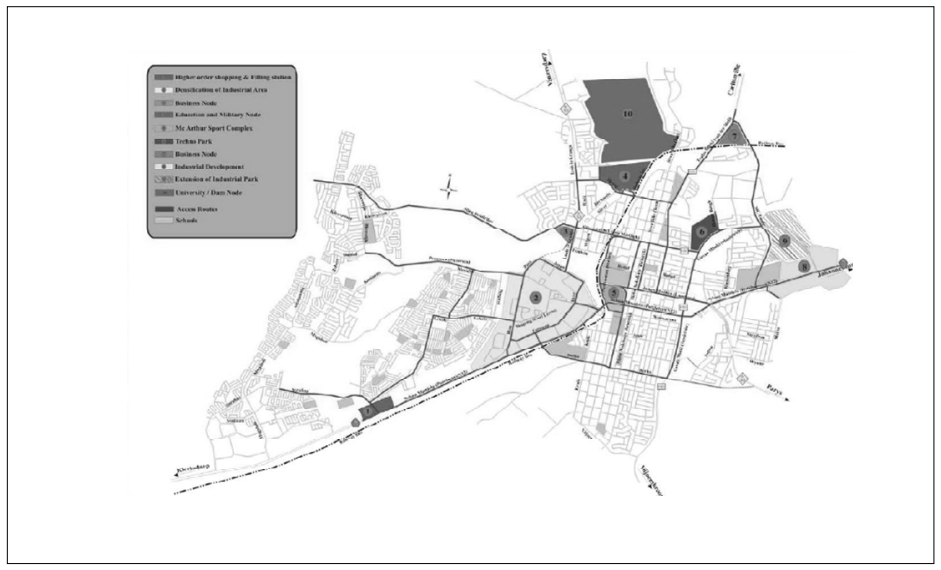

Source: TLM IPT [4].

Figure 2: $\quad$ Road network serving the intra-traffic movements within TLM.

\section{Modelling literature overview}

Bhat et al. [5], Chang [6] and Crecine [10] examine existing literature to determine how effectively the current transport and land-use models can be applied as to analyze the integration and interface between land use and transport [3]. This interface can best be described by considering the theoretical, methodological and operational characteristics of the respective models. 
Table 1 represents a comparison of all models that are applied to analyze the interface between land use and transport based on the common denominators (factors) supporting each of the models. The different categories include spatial interaction models; econometric models and micro-simulation models. This differentiation is based on the methodology relationship where the primary objective is to describe the integration between transport and land-use. From the perspective of this paper the relationship selection was restricted to commercially application models with the exclusion of regional economic models.

Table 1: $\quad$ Classification of land use and transportation models.

\begin{tabular}{|c|c|c|c|c|}
\hline \multicolumn{5}{|c|}{ Land Use and Transportation Models } \\
\hline \multirow[b]{2}{*}{\begin{tabular}{|c} 
Spatial Interaction/ Gravity- \\
Based Models \\
\end{tabular}} & \multirow[b]{2}{*}{ Econometric Models } & \multicolumn{3}{|c|}{ Micro-simulation Models } \\
\hline & & Agent-based Models & $\begin{array}{l}\text { Activity-Based } \\
\text { Models }\end{array}$ & \begin{tabular}{|l} 
Cell-based \\
Models \\
\end{tabular} \\
\hline $\begin{array}{c}\text { METROPOLUS = EMME } / 2+ \\
\text { TRANPLAN=Enhanced(ITLUP) } \\
\text { (cf. [6]) }\end{array}$ & $\begin{array}{l}\text { CATLAS (Applied to } \\
\text { Chicago) (cf. [8]) }\end{array}$ & \multicolumn{2}{|c|}{$\begin{array}{c}\text { TASHA (Applied in Canada) }=(\text { EMME or MATSIM) + } \\
\text { CALMET + CALPUFF + MOBILE6.2C (cf. [9]) }\end{array}$} & \multirow{7}{*}{\begin{tabular}{|c|} 
MALUT $=$ CA \\
Model + micro- \\
simulation \\
transport model \\
(cf. [15])
\end{tabular}} \\
\hline TOMM (cf. [10]) & $\begin{array}{c}\text { METROSIM (Applied to } \\
\text { NY) = Enhanced (CATLAS) } \\
\text { (cf. [11]) }\end{array}$ & ILUTE $=$ Use(TASHA) (cf. [9]) & $\begin{array}{c}\text { CEMDAP (Applied } \\
\text { to Dallas and LA) } \\
\text { (cf. [5]) }\end{array}$ & \\
\hline PLUM (cf. [12]) & \begin{tabular}{|c} 
NYMTC-LUM (Applied to \\
NY) $=$ \\
Refined(METROSIM) (cf. \\
{$[13]$ ) } \\
\end{tabular} & ILUMASS (cf. [9]) & $\begin{array}{l}\text { FAMOS (Applied in } \\
\text { Florida) (cf. [14]) } \\
\end{array}$ & \\
\hline $\begin{array}{l}\text { ITLUP (Applied in the USA, very } \\
\text { old technology) = } \\
\text { DRAM+EMPAL+CALIB (cf. [16]) }\end{array}$ & \begin{tabular}{|c} 
DELTA (Applied in UK and \\
part of Western EU) (cf. \\
{$[17]$ ) } \\
\end{tabular} & $\begin{array}{l}\text { Ramblas (Applied in the } \\
\text { Nederlands) (cf. [18]) }\end{array}$ & \begin{tabular}{|c|} 
SFCTA (Applied to \\
San Francisco) (cf. \\
{$[19]$ ) } \\
\end{tabular} & \\
\hline LILT (Applied to Leeds) (cf. [20]) & $\begin{array}{l}\text { MUSSA (Applied in } \\
\text { USA)=Cube land (cf. [21]) }\end{array}$ & UrbanSim (cf. [22]) & & \\
\hline \multirow[t]{2}{*}{ IRPUD (cf. [23]) } & & $\begin{array}{l}\text { LUTI (Applied on Edinburgh } \\
\text { and Manchester) = TRAM + } \\
\text { DELTA (cf. [24]) }\end{array}$ & & \\
\hline & & \begin{tabular}{|l|} 
MARS=UDM (Applied to \\
Leeds, Helsinki, Edinburgh, \\
Madrid, Oslo, Stockholm, \\
Vienna, Chiang Mai, Hanoi) = \\
Dynamic LUTI model \\
(Vensim software) (cf. [25]) \\
\end{tabular} & & \\
\hline
\end{tabular}

Source: own construction.

\section{Land use and traffic survey patterns}

The principles of the land use and traffic modelling approach were applied to the land use and traffic survey data for the study area (TLM). The current traffic congestion and conflict is due to the fact that the interface and integration of land use and transport is not recognized as an important focus by TLM. Therefore a detailed land use and traffic survey for the TLM Central Business District (CBD) was undertaken. This includes all inter- and intra-traffic modal split data and was supported by an analysis of all land use (zoning) data and the actual dominant uses of land within the TLM.

The land use zonings within the study area are depicted in Figure 3 whilst the total traffic movements in terms of modal split (peak traffic volumes only) are 
super-imposed on this figure. The core traffic data (total traffic and peak traffic flow) is shown in Table 2. The traffic data includes the availability of parking statistics within the study area.

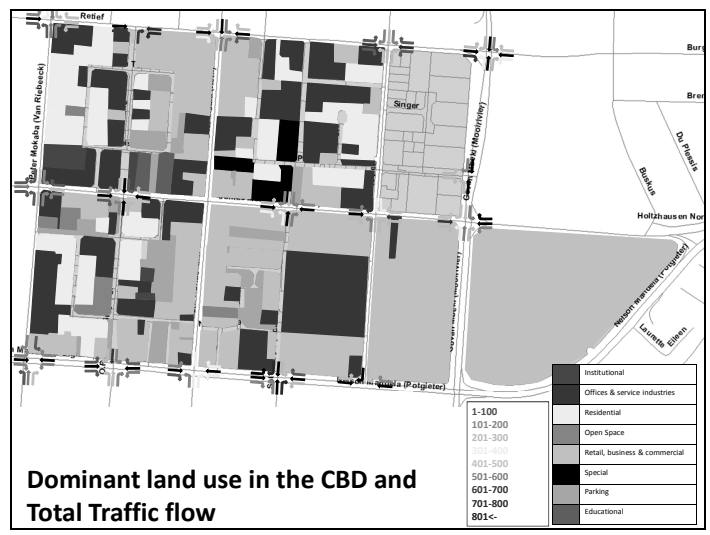

Source: own construction from land use and traffic surveys, 2012.

Figure 3: Land use zonings and total peak hour traffic within the study area.

Table 2: $\quad$ Total peak hour traffic flow per modal split within the study area.

\begin{tabular}{|l|l|l|l|l|}
\hline \multicolumn{1}{|c|}{ Mode of traffic } & $\begin{array}{c}\text { Total traffic per } \\
\text { day }\end{array}$ & $\%$ & $\begin{array}{c}\text { Peak hour traffic } \\
\text { flow }\end{array}$ & $\%$ \\
\hline Light Motor Vehicles (LMV) & 11,672 & 84.09 & 2462 & 84.49 \\
\hline $\begin{array}{l}\text { Service Delivery Vehicles } \\
\text { (DMV) }\end{array}$ & 670 & 4.83 & 112 & 3.86 \\
\hline Heavy Motor Vehicles (HMV) & 131 & 0.94 & 82 & 2.81 \\
\hline Mini-bus Taxis & 625 & 4.50 & 125 & 4.26 \\
\hline Motor cycles & 26 & 0.19 & 24 & 0.80 \\
\hline Total motorized traffic & 13,124 & 94.55 & 2805 & 96.22 \\
\hline Bicycles & 131 & 0.94 & 30 & 1.03 \\
\hline Pedestrians & 1263 & 9.10 & 80 & 2.74 \\
\hline Non-motorized traffic & 1394 & 9.60 & 110 & 3.77 \\
\hline Total traffic & 14,518 & 100.00 & 2915 & 100.00 \\
\hline
\end{tabular}

Source: own construction from traffic survey.

\section{Development pressures, factors and impacts}

The development pressures and factors (catalysts) for both present and future land use and transport within the TLM are illustrated in Figure 4 (Local spatial development framework (LSDF) [4].

From Figures 2 and 3 the interface, integration and alignment between land use and transportation within the study area can be deduced. Furthermore, traffic data, planned spatial development, functionality of the road network and the nature of the traffic congestion can clearly be deduced. The basis for this is the fact that land use and transportation is not integrated and shows high degree of 


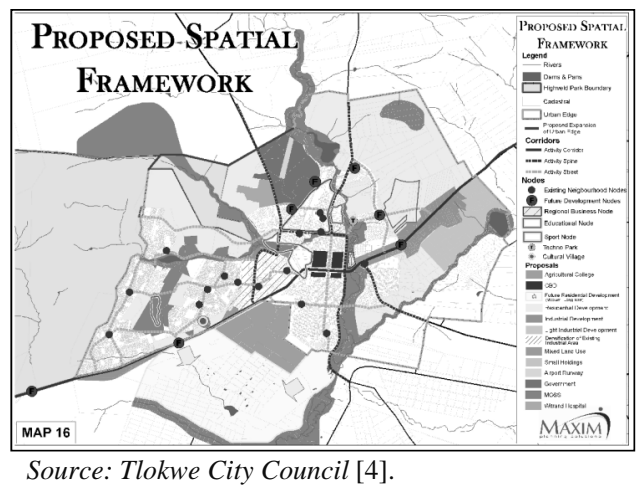

Figure 4: $\quad$ SDF for the study area.

conflict to the detriment of road users and pedestrians. Therefore the need to analyze this interface scientifically through application of elementary modelling is thus evident.

\section{Elementary modelling methodology}

This paper reports on the application of an elementary and basic land use and transport modelling approach as to define the nature of the interface, need for integration and to motivate TLM to implement trans-disciplinary [1] focus in spatial and transportation planning. Due to the lack of origin and destination data availability, the modelling methodology will be based on conclusions deduced from existing and projected traffic flow patterns, need for additional land in the $\mathrm{CBD}$ as retail, commercial and office space, need for parking provision and development of an effective pedestrian and non-motorized transportation routes within the CBD.

\subsection{Formulation of modelling objectives}

The following specific modelling objectives in goal realization are applicable:

- Objective 1: Addressing the current traffic congestion due to conflicting inter- and intra-traffic patterns.

- Objective 2: Optimization of land use development, traffic and environmental relationships and its related impacts.

- Objective 3: Improved accessibility within the CBD through provision of spatially well located parking areas to serve the high intensive land zoning in terms of supply and demand factors.

\subsection{Modelling attributes}

The following traffic attributes are included in this basic modelling exercise: places of education; commercial land uses; social and recreation areas; location of employer business areas; location of non-home based employer businesses; 
service industry businesses; residential related land development and other related land uses.

\section{$7 \quad$ Land use and transportation modelling application}

Traffic and land use surveys were conducted in 2012 to determine the existing trip distribution and land uses in the CBD. The traffic data survey included morning and afternoon peak traffic per mode. The zone size included 10 internal counting points and two (2) (East and West) external counting point (N12 route). The intra-traffic count included 37 intersections and 72 road links. The modes of transport modelled include motorized, (LMV, SDV, HMV, Mini-bus Taxis and Motorcycles) and non-motorized traffic (pedestrians and bicycle) movements. Base year 2012 and mid-future 2015 and 2021 matrices based on land use predictions (floor space, employment and spatial area of developed land) for predicted traffic movements and land use patterns have been calculated based on scientific projection methods. Where applicable the existing land use and transport modelling were based on trip generation, distribution, mode choice models, route choice and traffic assignment modelling. EMME 4 applications were applied to the inter-traffic routes based on existing information on origin and destination figures and data obtained from the weight bridge on the N12 Route East of the study area.

\section{Findings of the research}

As described in the hypothesis to the research problem, the following findings related to land use and transport were made based on the modelling application:

\subsection{Transport movement impacts}

The conflict between inter- and intra-traffic was clearly evident from the modelling application. This is being aggregated through internal development pressures being exerted through the increase in demand for new commercial and office space based on urban regeneration and redevelopment within the study area. Densification within the existing land use structure is also evident if the number of new shopping malls and building plans is considered. These developments will place a further load on the existing road network in terms of traffic flow patterns and the associated demand for additional parking.

In terms of the modelling undertaken it is estimated that the current road network serving the intra-traffic volumes is $37 \%$ under designed (based on design capacity for Class 5 Roads of $400 \mathrm{pcu} / \mathrm{h}$ peak hour vehicle movements vs. $550 \mathrm{pcu} / \mathrm{h}$ taken up during the survey $[3,26]$. This includes under capacity in terms of both geometrical structural design standards Class 5 Residential Roads being used for intra-traffic distribution. This clearly is illustrative of the lack of recognition and application of applicable geometric road design standards and spatial development approaches and needs as contained in the LSDF [4]. 
As far as inter-traffic is concerned the major impact relates to the traffic link from east to west (N12 Route) (inclusive of the south/north spine) defining the boundary of the CBD. This road link carries all modes of traffic with a non-local destination. Some 13495 vehicles peak hour movements (both directions) are experienced. Due to a restriction on speed the design parameters for the existing two lane roadways with two ways traffic is exceeded due to 10 intersections with robots bringing the average speed per vehicle down to $28 \mathrm{~km} / \mathrm{h}$.

Through the modelling exercise an expected growth of $2.67 \%$ /annum is estimated. The existing design capacity of the N12 (Class 4 Road) route is $1200 \mathrm{pcu} / \mathrm{h}$. In practice only some 480 to $845 \mathrm{pcu} / \mathrm{h}$ is accommodated. This implies that the road capacity is exceeded by more than $50 \%$. It clearly indicates that in terms of road network planning for inter-traffic the N12 Route through the study area is under-designed in terms of geometric as well as structural design capacities. The position in future will further deteriorate. Urgent attention should thus be given to re-route the inter-traffic through a by-pass higher order road link (Class 1 Road) to the south of the urban boundary.

\subsection{Transport road network and pattern}

Spatially the road network underpinning the CBD (study area) is dominated by a grid road system with intersections spaced on average between 310 metres and 420 meters apart. This implies that traffic patterns in the study area are dominated by relative short road links and numerous intersections. This position should be addressed by a one way road distribution and collector system consisting of outer and inner road linkages with limited four way stop intersections. The identified road ways should be identified based on the alignment that identifies and dissects the core business area of the CBD from its transition (border) area. These routes were identified based on dominant land zoning, frontage distances, height and density based on zoning categories in terms of the Town Planning Scheme (TPS) [27]. The principles of the central business index method (CBI), central business height index (CBHI) and central business intensity index (CBII) were applied to the land use data and zonings within the study area based the techniques as developed by Murphy and Vance [28, 29], Chapin [30] supported by those of Murphy [31]. This demarcation is supported by the elementary modelling methodology as discussed above.

\subsection{Need and demand for parking}

The analysis through the modelling indicated that parking is not being provided in terms of optimal location and space relationships [32]. The quantum as well as the quality (safety and convenience considerations) impacted negatively on the supply of parking to clients. Parking along the pavements within the CBD is on average 11 parking spaces for every $53 \mathrm{~m}$ of business frontage.

Due to the physical short block/intersection distances and local shopping preference, clients visiting the CBD clearly show travel patterns of 'jay-riding' whereby shoppers are driving around street blocks to find parking as close as 
possible to a shop to be visited thereby creating additional traffic volume loads and increased intra-traffic congestion.

Parking provision is arranged and regulated by the TPS [27] and generally requires 6 parking bays per $100 \mathrm{~m}^{2}$ of business area (floor space) in the case of new shopping centres and 2 parking bays $/ 100 \mathrm{~m}^{2}$ of gross leaseable business floor area. From the survey the total number of parking bays provided represents some 4532 parking bays. This land use represents 13.6 ha within the CBD area of 87ha gross leasable floor space.

The assessment of the location and accessibility clearly indicated specific needs in certain geographic areas within the CBD for further parking development. In order to accommodate future growth, the TLM should consider locating new parking areas on the existing Residential 1 land within the inner link road sectors and outer ring road as proposed above. An estimated 7394 parking bays will be required in order to address the current backlog and to accommodate the development of further business growth and development by 2017. This will require some 8.58 ha additional land for parking. This parking provision may be provided within basements, ground level or first floor levels on new business and office development within the CBD. An additional 15 parking bays will have to be provided for a new mini-bus taxi facility within the CBD preferably on the outer-ring road.

\subsection{Loading and off-loading facilities}

In $85 \%$ of the cases businesses depends on loading and off-loading facilities provided along the road ways in front of existing businesses. This leads to 'double parking' by HMV when off loading takes place that disturbs traffic flow and jeopardise safety of pedestrians. More stringent requirements should be applied in future development to ensure that businesses shares communal loading and off-loading facilities provided away from the road network, in between buildings. The implementation of this should be provided for within a CBD Regeneration Plan (URP) and be enforced through the TPS.

\subsection{Pedestrian movement patterns}

Pedestrian movement in the CBD is predominantly provided for within the shoulder of the road system. This practice, from the survey and modelling results are insufficient and should be addressed through dedicated pedestrian and other non-motorized lanes. The present pedestrian movements are focussed on the existing Mini-bus Taxi Terminus along all roads (both sides on the road shoulder). This pedestrian network is linked to all larger shopping malls. This need should be addressed through the URP and needs to include high quality pedestrian corridors based on effective urban design criteria.

\subsection{Land-use/economic impacts and patterns}

Table 3 show the summary of the related future spatial land use and traffic impacts within the CBD of the study area. 
Table 3: $\quad$ Model Forecasts (20 year) spatial land-use and traffic impacts.

\begin{tabular}{|c|c|c|}
\hline Measure/Effect & $\begin{array}{l}\text { Present } \\
2012\end{array}$ & $\begin{array}{l}\text { Future Forecasts an supportive } \\
\text { interventions } 2032\end{array}$ \\
\hline $\begin{array}{l}\text { Land-use } \\
\text { transportation } \\
\text { patterns }\end{array}$ & $\begin{array}{l}\text { - Mixed business, retail and office } \\
\text { space. } \\
\text { - Two way traffic within a grid } \\
\text { layout pattern with high number } \\
\text { of street crossing. } \\
\text { - No road hierarchy exists. } \\
\text { - Inter and intra traffic congestion } \\
\text { and clashes. }\end{array}$ & $\begin{array}{l}\text { - Identified higher order outer ring road } \\
\text { bounded by double road way mixed } \\
\text { with one way traffic movement system. } \\
\text { - Outer ring road to be supported by } \\
\text { inner ring road links providing optimal } \\
\text { access through an adopted one way } \\
\text { traffic system. } \\
\text { - Construction of new by-pass road to re- } \\
\text { route inters traffic. }\end{array}$ \\
\hline Parking need & $\begin{array}{l}\text { - } 4532 \text { parking spaces (13.6ha of } \\
\text { land within CBD) }\end{array}$ & $\begin{array}{l}\text { - Further } 2862 \text { parking spaces or 8ha of } \\
\text { land area distributed within the present } \\
\text { residential land within the CBD. } \\
\text { - Provision of safe parking areas. }\end{array}$ \\
\hline $\begin{array}{l}\text { Loading and off- } \\
\text { loading facilities }\end{array}$ & $\begin{array}{l}\text { - } 183 \text { parking bays ( } 8.4 \text { ha of land } \\
\text { within CBD) }\end{array}$ & $\begin{array}{l}\text { - Reorganisation of exiting loading and } \\
\text { off loading practices. } \\
\text { - Split loading and off loading activities } \\
\text { beyond shopping hours. } \\
\text { - Application of urban regeneration } \\
\text { strategy. } \\
\text { - Provision of new Mini-bus Taxi facility }\end{array}$ \\
\hline $\begin{array}{l}\text { Pedestrian } \\
\text { movement patterns }\end{array}$ & - $31 \mathrm{~km}$ of pedestrian walkways. & $\begin{array}{l}\text { - Identification of new pedestrian routes } \\
\text { to link mass parking areas and core } \\
\text { businesses. } \\
\text { - Upgrading of street furniture and street } \\
\text { fronts of buildings. }\end{array}$ \\
\hline $\begin{array}{l}\text { Cost of locating } \\
\text { businesses in the } \\
\text { CBD }\end{array}$ & - $\mathrm{R} 27000 / \mathrm{m}^{2}$ & - $\mathrm{R} 84000 / \mathrm{m}^{2}$ \\
\hline $\begin{array}{l}\text { Employment levels } \\
\text { within the CBD }\end{array}$ & - Approximately 3200 jobs & - Estimated at 5980 jobs \\
\hline $\begin{array}{l}\text { Business-to- } \\
\text { business } \\
\text { interaction }\end{array}$ & - Isolated & $\begin{array}{l}\text { - Integration between mixed land uses, } \\
\text { parking availability, pedestrian } \\
\text { movement and improved loading and } \\
\text { off loading facilities }\end{array}$ \\
\hline $\begin{array}{lr}\text { Total floor } & \text { space } \\
\text { occupied } & \text { by } \\
\text { activities } & \end{array}$ & - 87 ha gross leasable area & $\begin{array}{l}\text { - 128ha gross leasable area (on all floors } \\
\text { with emphasis on vertical densification) }\end{array}$ \\
\hline $\begin{array}{l}\text { Road network } \\
\text { characteristics and } \\
\text { traffic flow }\end{array}$ & $\begin{array}{l}\text { - Intra-traffic based on two } \\
\text { directional traffic lanes within } \\
\text { existing grid layout. } \\
\text { - Through traffic integrated with } \\
\text { intra-traffic }\end{array}$ & $\begin{array}{l}\text { - Introduction of one way outer ring road } \\
\text { for intra-traffic flow and movements. } \\
\text { - Outer ring road supported by internal } \\
\text { one way road links to enhance capacity } \\
\text { and traffic and intra-traffic flow. } \\
\text { - Construction of new Class } 1 \text { Road By- } \\
\text { pass road as to divorce intra- and inter } \\
\text { traffic flows. }\end{array}$ \\
\hline
\end{tabular}

Source: own construction from survey, 2012

\section{Conclusions}

From the research the following conclusions can be drawn:

- The lack of origin and destination data restricts the application of EMME 4 land use and transportations modelling within the study area.

- The elementary modelling methodology for intra-traffic movements indicated that it is possible to apply other techniques of transportation and land use modelling such as forecasting of future development; theory of travel choice 
behaviour; analysis of network data; trip generation modelling; trip distribution models, modal choice models and traffic assignment allocation models.

- Inter-traffic modelling can be estimated through application of the EMME 4 transportation modelling software.

- Table 3 constitutes the envisaged interventions and projects to be implemented based on the deductions from the application of the elementary land use and traffic model and approach as described in this paper.

- The construction of a new Class 1 Road (freeway) to the south of the town to address the traffic conflict and congestion between inter-traffic and intratraffic movements.

- Application of land use and transportation modelling before application of spatial and development frameworks will improve the quality of the built environment and movement patterns within regional and urban space.

\section{References}

[1] Litman, T.A. (2012) Land Use Impacts on Transport. www.vti.org.

[2] Mackett, R., (1981) The impact of transport planning policy on the city; a model-based approach applied to Leeds, PhD thesis, University of Leeds.

[3] Traffic Surveys carried out by North West University: Research Unit for Environmental Sciences and Management: Sub-Programme 5: Sustainable Planning, Development and Implementation (2012).

[4] Tlokwe City Council IDP 2007; SDF 2008 and ITP, 2008.

[5] Bhat, C.R., Guo, J.Y., Srinivasan, S., and Sivakumar, A., (2004) A Comprehensive Econometric Microsimulator for Daily Activity-Travel Patterns, Transportation Research Record, Vol. 1894, pp. 57-66.

[6] Chang, Justin S., Models of the relationship between Transport and LandUse: A Review, Transport Reviews, Vol. 26, No. 3, 325-350, 2006.

[7] Iacono Michael, Levinson David, El-Geneidy Ahmed, Models of Transportation and Land Use Change: A Guide of the Territory, Journal of Planning Literature, Vol. 22, No. 323, 2008.

[8] Anas, Alex, (1982) Residential location markets and urban transportation: Economic theory, econometrics and policy analysis with discrete choice models. New York: Academic Press.

[9] Salvani, Paul, and Eric J. Miller., (2005) ILUTE: An operational prototype of a comprehensive micro simulation model of urban systems. Networks and Spatial Economics 5(2): 217-34.

[10] Crecine, J. P., (1964) TOMM. Pittsburgh: Department of City and Regional Planning.

[11] Anas, Alex, and Richard J. Arnott, (1994) The Chicago prototype housing market model, with tenure choice and its policy implications. Journal of Housing Research 5:73-129.

[12] Goldner, W., (1971) The Lowry model heritage. Journal of the American Institute of Planners 37:100-10. 
[13] Anas, Alex, (1998) NYMTC transportation models and data initiative. The NYMTC Land Use Model. Williamsville, NY: Alex Anas \& Associates.

[14] Pendyala, R.M., Kitamura R., Kikuchi A., Yamamoto T., and Fujii S., (2005) FAMOS: The Florida Activity Mobility Simulator. Transportation Research Record 1921, Journal of the Transportation Research Board, TRB, National Research Council, Washington, D.C., pp. 123-130.

[15] Kii, Masanobu, and Kenji Doi, (2005) Multi-agent land-use and transport model for the policy evaluation of a compact city. Environment \& Planning B: Planning and Design 32(4): 485-504.

[16] Putman, Stephen H., (1974) Preliminary results from an integrated transportation and land use models package. Transportation 3(3): 193-224.

[17] Simmonds, David., (1999) The design of the DELTA land-use modelling package. Environment \& Planning B: Planning and Design 26:665-84.

[18] Veldhuisen, K. Jan, Harry J. P. Timmermans, and Loek L. Kapoen., (2000) Ramblas: A regional planning model based on the micro simulation of daily travel patterns. Environment \& Planning A 32(3): 427-443.

[19] Bradley, Mark A. and Bowman John L., (2006) A Summary of Design Features of Activity-Based Micro simulation Models for U.S. MPOs, white paper presented at the TRB Conference on Innovations in Travel Demand Modeling, May 21-23, 2006, Austin, Texas.

[20] Mackett, Roger L., (1983) The Leeds integrated land-use transport model (LILT). Crowthorne, UK: Transport and Road Research Laboratory.

[21] Martinez, Francisco J., (1992) The bid-choice land use model: an integrated economic framework. Environment \& Planning A, 24: 871-85.

[22] Waddell, Paul A., A. Borning, M. Noth, N. Freier, M. Becke, and G. Ulfarsson., (2003) Micro simulation of urban development and location choices: Design and implementation of UrbanSim. Networks and Spatial Economics 3(1): 43-67.

[23] Wegener, Michael., (1982) Modelling urban decline: A multi-level economic-demographic model of the Dortmund region. International Regional Science Review 7(1): 21-41.

[24] Wegener, M. (2004). Overview of Land Use Transport Models. Handbook of transport geography and spatial systems, D. A. Hensher, ed., Elsevier, Amsterdam; Oxford.

[25] Pfaffenbichler, P. C. (2003). The strategic, dynamic and integrated urban land use and transport model MARS (Metropolitan Activity Relocation Simulator). Development, testing and application. Dissertation, Vienna University of Technology, Vienna.

[26] CSIR, 1994. Guidelines for Engineering Services in Residential Townships. Pretoria.

[27] Potchefstroom Town Planning Scheme. 1980. Tlokwe Local Municipality.

[28] Murphy, R.E. and Vance, J.E. (1954a) A comparative study of nine central business districts. In: Economic Geography, Vol. 30, pp. 301-336.

[29] Murphy, R.E. and Vance, J.E. (1954b). Delimiting the CBD. In: Economic Geography, Vol. 30, pp. 189-222. 
[30] Chapin, F.S. (1972) Urban Land Use Planning. University of Illinois Press. Chicago.

[31] Murphy R.A. (1971) The Central Business District. Longman Press. London.

[32] Manville, M. and Shoup, D. (2005): People, parking and Cities. Journal of Urban Planning and Development. American Society of Civil Engineers. pp. 233-245. 